\title{
Buying Trouble? The Impact of Foreign Assistance on Conflict in Direct and Indirect Rivalry Situations ${ }^{1}$
}

\author{
Peter Rudloff \\ Oklahoma State University \\ James M. Scott \\ Texas Christian University
}

\begin{abstract}
States provide foreign assistance for many reasons, including their achievement of strategic goals. Previous research suggests that rivalries exert a meaningful impact on foreign aid allocations, not only in direct rivalry situations (i.e., rivals are less like to receive aid), but also in indirect rivalry situations (i.e., potential recipients located near rivals or with rivalries in common with the donor are more likely to receive aid). What happens as a consequence of such strategic aid allocations? In this paper, we examine the effect of foreign aid on conflict within direct and indirect rivalry situations. Specifically, we identify and develop two contending arguments about the likely consequences of foreign aid and conflict in indirect rivalry situations. To test these arguments, we examine foreign assistance by the United States and the conflict history of recipient states from 1962 to 2000. Our results indicate that when foreign aid recipients and donors are rivals with a third state, increased foreign aid to the recipient leads to increased conflict between the recipient and the third-party rival
\end{abstract}

Keywords: foreign aid, rivalry, conflict

\section{Introduction}

Strategic calculations play important roles in foreign aid allocations, as donors attempt to use aid to achieve a variety of policy goals. Aid allocations are thus complex decisions involving a variety of factors, among which are donors' strategic rivalries. ${ }^{2}$ Not surprisingly, direct rivalry situations - long-term, persistent confrontations between pairs of states involving relatively frequent uses of force - are powerful determinants of assistance (i.e., rivals are less likely to receive aid). ${ }^{3}$ However, 'indirect rivalry' situations also play a role. As a recent analysis indicates, donors appear to allocate greater amounts of aid to recipients located near their rivals (neighbors of rivals) and to those with rivalries in common with the donor (shared rivals). ${ }^{4}$

What happens after major powers such as the United States (US) extend foreign

Peter Rudloff, Assistant Professor. Department of Political Science, Oklahoma State University. Email: peter.rudloff@okstate. edu. James M. Scott, Professor. Department of Political Science, Texas Christian University. Email: j.scott@tcu.edu.

Previous versions of this paper were presented at the International Studies Association - Midwest conference in 2011 and the University of Illinois Department of Political Science Alumni Conference in 2012. The authors would like to thank Caileigh Glenn for valuable research assistance, the panel participants and audiences at the conferences, and the anonymous reviewers of this manuscript for their comments and suggestions.

2 R.D. McKinlay and R. Little, "A foreign policy model of US bilateral aid allocation," World Politics 30 (1977): 58-86; Peter Rudloff, James M. Scott, and Tyra Blew, "Countering Adversaries and Cultivating Friends: Indirect Rivalry Factors and Foreign Aid Allocation," Cooperation and Conflict 48 (2013): 401-423.

3 McKinlay and Little, "A foreign policy model."

4 Rudloff, Scott and Blew, "Countering Adversaries." 
assistance to countries with strategic rivalries involving the donor state? Does the provision of assistance ward off attacks on the aid recipient, or does it invite such attacks? Might such aid lead the recipient to initiate its own use of force? In short, do donors provide and improve security and defense, or do they actually buy trouble for those they aid and, perhaps, for themselves as well? The implications of these questions are significant, given that foreign aid can be distributed for many different purposes. ${ }^{5}$ Donors may distribute aid to achieve a foreign policy goal, only to discover that the assistance also encourages militarized behavior that runs counter to their initial purposes. ${ }^{6}$

In this analysis, we examine the effects of foreign aid on conflict within direct and indirect rivalry situations. After situating our analysis in the relevant literatures, we identify and develop two contending arguments about the likely consequences of foreign aid and conflict in indirect rivalry situations. To test these contending arguments, we examine foreign assistance by the US and the conflict history of recipient states from 1962 to 2000 . Our results lend support to the conclusion that when foreign aid recipients and donors are rivals with a third state, increased foreign aid to the recipient leads to increased conflict between the recipient and the third-party rival.

\section{Foreign Aid, Rivalries, and Conflict}

How does foreign aid affect the likelihood of conflict among aid recipients who share a rival with the donor or who are geographically close to donor rivals? A great deal of literature addresses the consequences of foreign aid. ${ }^{7}$ However, relatively few scholars focus on how foreign aid affects violence or conflict behavior, and these studies typically seek to explain conflict within states. ${ }^{8}$ Some studies examine whether aid affects conflict between states, but they vary significantly in their conclusions: some scholars find that aid contributes to security and peace, and others conclude that it contributes to conflict, arms races, and other confrontational behavior. ${ }^{9}$ However, there is nothing inherent in foreign aid that suggests the

5 McKinlay and Little, "A foreign policy model"; James H. Lebovic, "National Interests and US Foreign Aid: The Carter and Reagan Years," Journal of Peace Research 25 (1988): 115-135; Steven Hook, Foreign Aid in the National Interest (Boulder, CO: Lynne Rienner Press, 1995); James Meernik, Eric L. Krueger and Steven C. Poe, "Testing models of U.S. foreign policy: foreign aid during and after the Cold War," Journal of Politics 60 (1998): 63-85; Peter J. Schraeder, Steven W. Hook, and Bruce Taylor, "Clarifying the Foreign Aid Puzzle: A Comparison of American, Japanese, French, and Swedish Aid Flows," World Politics 50 (1998): $294-323$.

6 See also Paul Collier and Anke Hoeffler, "Unintended Consequences: Does Aid Promote Arms Races?" Oxford Bulletin of Economics and Statistics 69, no.1 (2007): 1-27; Patricia L. Sullivan, Brock C. Tessman and Xiaojun Li, "US Military Aid and Recipient State Cooperation," Foreign Policy Analysis 7 (2011): 275-294.

On the nature and purposes of foreign aid, see Carol Lancaster, Foreign Aid: Diplomacy, Development and Domestic Politics (Chicago: University of Chicago Press, 2007); Judith Tendler, Inside Foreign Aid (Baltimore: Johns Hopkins University Press, 1975); Vernon W. Ruttan, United States Development Assistance Policy: The Domestic Politics of Foreign Aid (Baltimore: Johns Hopkins University Press, 1996). Many studies examine its economic and political consequences for recipients: R. Cassen, Does Aid Work? 2nd Ed. (Oxford: Clarendon Press, 1994); P.M. Regan, "U.S. Economic Aid and Political Repression: An Empirical Evaluation of U.S. Foreign Policy," Political Research Quarterly 48 (1995): 613-628; G. Crawford, "Foreign Aid and Political Conditionality: Issues of Effectiveness and Consistency," Democratization 4 (1997): 69-108; C. Burnside, and D. Dollar, "Aid, Policies and Growth," American Economic Review 90 (2000): 847-868; P. Collier and D. Dollar, Development Effectiveness: What Have We Learned? (Washington, DC: World Bank, 2001); W. Easterly, The White Man's Burden: Why the West's Efforts to Aid the Rest Have Done So Much Ill and So Little Good (New York: Penguin, 2006); S. Knack, "Does Foreign Aid Promote Democracy?" International Studies Quarterly 48 (2004): 251-266.

8 Paul Collier and Anke Hoeffler, "Aid, Policy, and Peace: Reducing the Risks of Civil Conflict," Defence and Peace Economics 13, no.6 (2002): 435-450; Max Blouin and Stéphane Pallage, "Humanitarian Relief and Civil Conflict," Journal of Conflict Resolution 52, no.4 (2008): 548-565; Joppe de Ree and Eleonora Nillesen, "Aiding Violence or Peace? The Impact of Foreign Aid on the Risk of Civil Conflict in Sub-Saharan Africa," Journal of Development Economics 88, no.2 (2009): 301-313; Richard A. Nielsen, Michael G. Findley, Zachary S. Davis, Tara Candland, Daniel L. Nielson, "Foreign Aid Shocks as a Cause of Violent Armed Conflict," American Journal of Political Science 55, no.2 (2011): 219-232.

9 Davis B. Bobrow, P. Terrence Hopmann, Roger W. Benjamin, and D. A. Sylvan, "The Impact of Foreign Assistance on National Development and International Conflict" Journal of Peace Science 1, no.1 (1973): 39-60; Paul Collier, Wars, Guns and 
conflict consequences of aid will be limited to the recipients' domestic politics (e.g., civil war). ${ }^{10}$

Foreign aid is an important foreign policy strategy for donors. ${ }^{11}$ While there are also domestic political factors at work, ${ }^{12}$ much research indicates that donors are substantially driven by strategic calculations in their aid allocation decisions and expect to derive political benefits from providing assistance. Indeed, security and strategic factors such as alliance concerns, ideological alignments, military deployments, and bases have all been found to influence aid decisions. ${ }^{13}$ Consequently, aid decisions are affected by the donor's economic, political, and security interests and by the recipient's economic and humanitarian needs. ${ }^{14}$

States rely on foreign aid in part because of its fungible nature and its potential contributions to a wide variety of purposes. ${ }^{15}$ Among other things, foreign aid may establish dependencies between the recipient and donor and may influence outcomes such as development, reform and observance of human rights, and internal conflict. ${ }^{16}$ The fungibility of aid, however, means that while the assistance may produce results in line with the donor's intentions and interests, it may also lead to a number of "unintended consequences," as recipients may divert resources and/or shift purposes. ${ }^{17}$

In fact, scholars are divided over whether the provision of foreign aid 'buys' influence for the donor. Some conclude that recipient behavior (in United Nations' voting, for example) converges with donor preferences and others argue that assistance has limited (or even opposite) effects. ${ }^{18}$ According to Mott, for example, rather than buying influence, US military aid has instead contributed to stronger, more assertive recipients who ignore US interests and pursue their own purposes. ${ }^{19}$ Similarly, Sullivan, Tessman, and Li conclude that greater US military aid mostly reduces recipient cooperation with the US. ${ }^{20}$

Foreign aid may be used by donors to further their security interests. Indeed, security concerns such as rivalries affect which states receive aid: a state rarely allocates aid to its

Votes: Democracy in Dangerous Places (New York: Harper, 2009); Collier and Hoeffler, "Unintended Consequences"; Tarhan Feyzioglu, Vinaya Swaroop and Min Zhu, "A Panel Data Analysis of the Fungibility of Foreign Aid," The World Bank Economic Review 12, no.1 (1998): 29-58; Nielsen et al., "Foreign Aid Shocks."

10 E.g., Collier and Hoeffler, "Unintended Consequences."

11 McKinlay and Little, "A foreign policy model"; A. Alesina, and D. Dollar, "Who gives foreign aid to whom and why?" Journal of Economic Growth 5 (2000): 33-63; Glenn Palmer, Scott B. Wohlander and T. Clifton Morgan, "Give or Take: Foreign Aid and Foreign Policy Substitutability," Journal of Peace Research 39 (2002): 5-26; Bjorn Hassler, "Foreign Assistance as a Policy Instrument: Swedish Environmental Support to the Baltic States, 1991-96," Cooperation and Conflict 37 (2002): 25-45; Christopher Fariss, "The Strategic Substitution of United States Foreign Aid," Foreign Policy Analysis 6 (2010): 107-131.

12 Carol Lancaster, Foreign Aid: Diplomacy, Development and Domestic Politics (Chicago: University of Chicago Press, 2007); Alain Noel and Jean-Philippe Therien "Political Parties and Foreign Aid," The American Political Science Review 94 (2000): 151-162; Ruttan, United States Development Assistance Policy; Tendler, "Inside Foreign Aid."

13 Palmer, Wholander and Morgan, "Give or Take," 8; McKinlay and Little, "A foreign policy model"; Lebovic, "National Interests and US Foreign Aid"; Meernik, Krueger and Poe, "Testing models of U.S. foreign policy"; Hassler, "Foreign Assistance"; Fariss, "The Strategic Substitution"; Robert K. Fleck and Christopher Kilby, "Changing aid regimes? US foreign aid from the Cold War to the War on Terror," Journal of Development Economics 91 (2010): 185-197; Rudloff, Scott and Blew, "Countering Adversaries."

14 McKinlay and Little, "A foreign policy model"; Lebovic, "National Interests and US Foreign Aid"; Hook, Foreign Aid; Meernik, Krueger and Poe, "Testing models of U.S. foreign policy"; Schraeder et al., "Clarifying the Foreign Aid Puzzle"; Fariss, "The Strategic Substitution"; Fleck and Kilby, "Changing aid regimes?."

15 Alesina and Dollar, "Who gives foreign aid"; Rudloff et al., "Countering Adversaries."

16 Hook, Foreign Aid; Lancaster, Foreign Aid; Nielsen et al., "Foreign Aid Shocks."

17 Collier and Hoeffler, "Unintended Consequences."

18 Karl Derouen and Uk Heo, "Reward, Punishment or Inducement? US Economic and Military Aid, 1946-1996," Defence \& Peace Economics 15, no.5 (2004): 453-470; Brian Lai and Daniel S. Morey, "Impact of Regime Type on the Influence of U.S. Foreign Aid," Foreign Policy Analysis 2, no.4 (2006): 385-404; Bruce E. Moon, "The Foreign Policy of the Dependent State," International Studies Quarterly 27 (1983): 315-340; William H. Mott, United States Military Assistance: An Empirical Perspective (Westport: Greenwood Press, 2002); Sullivan et al., "US Military Aid."

19 Mott, United States Military Assistance.

20 Sullivan et al., "US Military Aid." 
rivals, and often directs its assistance to states geographically near a rival and/or sharing a common rival with the donor. ${ }^{21}$ This is unsurprising given the consequences of rivalry for a wide variety of foreign policy behaviors. ${ }^{22}$ In particular, the importance of rivalry in explaining the occurrence of conflict between states ${ }^{23}$ suggests that foreign aid may interact with rivalry in important ways to either increase or decrease the likelihood of military conflict involvement among recipients and their rivals. ${ }^{24}$

While foreign aid may help to achieve a variety of foreign policy goals, ${ }^{25}$ it may also lead to conflict, either as a consequence of a donor's intent, or as an above-mentioned unintended consequence, ${ }^{26}$ based instead on the goals of the recipient country and its increased ability to pursue them. ${ }^{27}$ In fact, there is little reason to believe that the impact of aid on conflict behavior will be consistent, given the wide variety of interests for both donors and recipients. This thinking is especially true in the context of rivalries and the provision of foreign aid shaped by such long-term confrontations.

As noted, donors are highly unlikely to provide foreign aid to their direct rivals. ${ }^{28}$ However, 'indirect rivalry factors' also impact aid allocations and thus also affect subsequent conflict behavior. According to Rudloff, Scott, and Blew, indirect rivalry factors involve the rivalries of donor states, which may lead to increased aid to states that either share the rivalry, or are located near the donor's rival. Three indirect rivalry factors are central: a) rivalries in common ('rivals of my rivals'), or situations in which third-party states are engaged in their own rivalries with a rival of a major power; b) neighbors of rivals, or situations in which third-party states are located in geographic proximity to the rival of a major power; and c) neighbor and rival situations, or situations in which the first two conditions are simultaneously combined - that is, when a third party state is geographically near a direct rival of a major power and shares a rivalry in common with the major power. ${ }^{29}$

In the context of these indirect rivalry factors, at least two contending logics may be in effect. As Rudloff, Scott, and Blew argue, there are many different motivations for a donor's decision to give aid to states near, or in a rivalry with, its own rivals. ${ }^{30}$ First, aid could be intended to deter other states from attacking the recipient, similar to the notion of "extended deterrence. ${ }^{" 31}$ In this case, the intent of the donor is to prevent conflict from occurring.

21 McKinlay and Little, "A foreign policy model"; Rudloff, Scott and Blew, "Countering Adversaries."

22 Paul F. Diehl and Gary Goertz, War and Peace in International Rivalry (Ann Arbor, MI: University of Michigan Press.2000); Michael G. Findley and Tze Kwang Teo, "Rethinking Third-Party Interventions into Civil Wars: An Actor-Centric Approach," Journal of Politics 68 (2006): 828-837; Michael P. Colaresi, Karen A. Rasler, and William R. Thompson, Strategic Rivalries in World Politics: Position, Space, and Conflict Escalation (Cambridge: Cambridge University Press, 2007); Eric W. Cox, Why Enduring Rivalries Do - or Don't - End (Boulder, CO: Lynne Rienner, 2010).

23 For example, in Akisato Suzuki and Neophytos Loizides, "Escalation of Interstate Crises of Conflictual Dyads: GreeceTurkey and India-Pakistan," Cooperation and Conflict 46 (2011): 21-39.

${ }_{24}$ Diehl and Goertz, War and Peace; Sara McLaughlin Mitchell and Brandon C. Prins, "Rivalry and Diversionary Uses of Force," Journal of Conflict Resolution 48, no.6 (2004): 937-961; Karen A. Rasler and William R. Thompson, "Contested Territory, Strategic Rivalry, and Conflict Escalation," International Studies Quarterly 50, no.1 (2006): 145-168; Colaresi, Rasler and Thompson, Strategic Rivalries; Daniel S. Morey, "Conflict and the Duration of Peace in Enduring Rivalries," Conflict Management and Peace Science 26, no.4 (2009): 331-345.

25 Palmer, Wholander and Morgan "Give or Take"; Fariss, "The Strategic Substitution."

26 Collier and Hoeffler, "Unintended Consequences."

27 Mott, United States Military Assistance; Sullivan et al., "US Military Aid."

28 Rudloff, Scott and Blew, "Countering Adversaries." On the further impact of rivalry, especially during the Cold War, see McKinlay and Little, "A foreign policy model"; Anne Boschini, and Anders Olofsgard, "Foreign Aid: An Instrument for Fighting Communism," Journal of Development Studies 43 (2007): 622- 648; James M. Scott, Deciding to Intervene: The Reagan Doctrine and American Foreign Policy (Durham: Duke University Press Yoon, 1996); and Findley and Teo, "Rethinking "Third-Party Interventions."

29 Rudloff et al., "Countering Adversaries."

30 Ibid.

31 E.g. Paul K. Huth, "Extended Deterrence and the Outbreak of War," American Political Science Review 82, no.2 (1988): 
Second, donor states may be more interested in increasing conflict between a recipient and its rival, in an attempt to decrease the security of its rival state. Although these two logics may lead to opposite consequences in terms of conflict behavior, Rudloff, Scott, and Blew only address the influence of rivalry on foreign aid decisions and do not examine whether increases or decreases in aid lead to more or less conflict. ${ }^{32}$ These potential consequences of inserting aid into indirect rivalry situations are the focus of this analysis. In the following section we build on and extend these theoretical ideas, developing hypotheses regarding the link between foreign aid given as a result of indirect rivalry, and conflict between rivals and recipients.

\section{Contending Arguments: the Consequences of Foreign Aid in Rivalry Situations}

How does foreign aid affect the conflict behavior of either the recipients or the rivals who were ultimately the cause of the donor's decisions to give aid? ${ }^{33}$ Previous work and its implications present two contending arguments on the effects of this foreign aid. On the one hand, as we discuss below, foreign aid might increase conflict, because if the donor or recipient share a common goal of weakening a rival state through conflict, aid is one means to strengthen the recipient's capability to do so. On the other hand, aid might decrease conflict, particularly if both the aid donor and recipient wish to deter the rival state. ${ }^{34}$ Which of these arguments is best supported by the empirical evidence? We develop the foundations for each argument and then test them against each other and the relevant empirical record from 1962 to 2000 to determine which is more accurate and to provide insights into the intentions of donors and recipients in these situations. To develop these contending arguments, we must first consider the intent of the foreign aid donor and recipient, and how the 'principal-agent problem' creates the possibility that aid may increase conflict, despite the best intentions of donors to use aid to promote stability. ${ }^{35}$

\subsection{Principal-agent problems and foreign aid}

Donors and recipients of foreign aid may be motivated by two very different purposes. Foreign aid donors such as the US may be motivated by a desire to protect other states from the aggression of its rivals. Conversely, aid donors may not be benevolently motivated, and may use aid as an instrument of aggression - encouraging states through aid to target its rivals. Moreover, recipients of foreign aid may have an interest in promoting their foreign policy goals by attacking or otherwise acting aggressively towards a donor's rival. Or, a recipient may wish to avoid or deter conflict with the donor's rival. ${ }^{36}$ At the intersection of these motivations are a number of interesting possibilities in terms of the role of aid in

32 Rudloff et al., "Countering Adversaries.'

33 See ibid.

34 Ibid.

35 For entries into the substantial principal-agent literature, see Jonathan Bendor, A. Glazer, and Thomas Hammond "Theories of Delegation," Annual Review of Political Science 4 (2001): 235-69; David Epstein and Sharyn O'Halloran, Delegating Powers: A Transaction Cost Politics Approach to Policy Making Under Separate Power (Cambridge: Cambridge University Press, 1999); and Roderick Kiewiet and Mathew McCubbins, The Logic of Delegation (Chicago: University of Chicago Press, 1991). On its application to international relations, see Michael Barnett and Martha Finnemore Rules for the World: International Organizations in Global Politics (Ithaca: Cornell University Press, 2004); Darren Hawkins, David Lake, Daniel Nielsen and Michael Tierney, eds. Delegation and Agency in International Organizations (New York: Cambridge University Press, 2006); Lyne, Mona, Daniel Nielsen and Michael J. Tierney, "Getting the Model Right: Single, Multiple and Collective Principals in Development Aid," in Delegation and Agency in International Organizations, ed. Hawkins et al. (New York: Cambridge University Press, 2006); Daniel L. Nielson and Michael J. Tierney, "Delegation to International Organizations: Agency Theory and World Bank Environmental Reform," International Organization 57, no.2 (Spring, 2003): 241-276.

36 Rudloff et al., "Countering Adversaries." 
influencing conflict.

One might conclude that the important theoretical argument rests entirely on the interests of donor and recipient, and whether these interests converge. However, the nature of the foreign aid relationship complicates the role interests play in the link between aid and conflict. Once donors give aid, recipient states exercise a great deal of latitude in their actions as a result of the aid, independent of the interests of the donor. ${ }^{37}$ This is not to argue that the interests of the donor are inconsequential in such a relationship. The transfer of aid can signal the intentions of the donor; acting counter to these intentions may lead to reductions in future assistance for the recipient. ${ }^{38}$ Donors will also carefully consider how aid is likely to be used prior to committing to a transfer of aid, and so will seek to avoid aid that is likely to lead to outcomes that run counter to their own goals.

Despite these possibilities, however, the fundamental reality is that donor states exercise little control over aid recipients once aid is given. This leads to a serious principal-agent issue in the aid relationship. The agent - in this case, the foreign aid recipient - can act relatively independently from the donor, and may choose to utilize aid in ways with which the donor disagrees. This principal-agent problem is key to understanding how foreign aid affects the conflict behavior of recipient states.

\subsection{Argument One: aid as a stabilizing factor}

Foreign aid may decrease the likelihood of conflict by deterring other states from acting against a recipient. Donors may give aid to states to increase the security of these states. ${ }^{39}$ Foreign aid may be thought of as a promise of future support if conflict increases between the recipient and the rival states. If the foreign aid recipient also has an interest in avoiding conflict, this aid may significantly decrease the likelihood of conflict, as the foreign assistance serves as a form of "extended deterrence." ${ }^{40}$ The donor's rival should be less likely to initiate conflict against the recipient state for fear that the donor would involve itself on the side of the recipient in the event of military conflict. Aid can therefore serve as an important signal to other states that donors are committed to protecting recipient states, particularly when both donor and recipient clearly prefer to avoid conflict.

Even in cases where a donor is indifferent to or prefers conflict between recipient and rival, foreign aid may decrease conflict by increasing the ability of defensive-minded recipients to further their goals. Aid may increase the capability of the target state, increasing the likelihood that the donor would prevail in a military conflict with the donor's rival, regardless of whether the foreign aid donor chose to intervene. This situation further compounds the rival's incentive to avoid conflict with the recipient. When donors and recipients both wish to avoid conflict, foreign aid can serve to promote these goals. Thus, according to Argument One:

H1a: Increased aid to neighbors/rivals in common decreases the use of force against the recipient by the donor's rival.

If aid recipients wish to avoid conflict, the second obvious result is that aid will be associated with less conflict initiated by the recipient. What if the recipient of foreign aid is not so pacifically inclined? Any aid given to the recipient (even if the donor intends for aid to

\footnotetext{
e.g., Mott, United States Military Assistance; Sullivan et al., "US Military Aid."

38 e.g., Crawford, "Foreign Aid."

39 Rudloff et al., "Countering Adversaries."

40 Huth, "Extended Deterrence."
} 
be used for defensive or deterrence purposes) could be used to engage in conflict with another state. There may be ways to avoid this principal-agent problem. For example, foreign aid donors can use the promise of future aid and good relations with the donor to constrain the provocative behavior of the recipient towards the donor's rival. For example, by maintaining significant aid ties with Israel, the US may have an increased ability to constrain Israel from attacking states such as Iran, which Israel views as a direct threat to its security. The key is the relative value that the foreign aid recipient places on future gains from this relationship versus the possible benefits from conflict in the short term. Additionally, because donors know that foreign aid could be used for purposes that do not align with its preferences, they should specifically target its aid to states that are likely to be swayed by this relationship. If a recipient values this relationship highly, we would expect conflict to be suppressed, as aid promotes more peaceful policies among recipients. Unlike hypothesis H1a, however, the primary effect is on the recipient's likelihood of initiating conflict against the donor's rival. Thus, Argument One also suggests:

\section{H1b: Increased aid to neighbors/rivals in common decreases the use of force by the recipient against the donor's rival.}

\subsection{Argument Two: aid as an aggravating factor}

In contrast to the first argument, contending logic suggests that foreign aid may increase the likelihood of conflict between the recipient and other states. In the previous two hypotheses, we assume that the donor state wishes to decrease conflict between its rival and the foreign aid recipient. However, it may be the case that the foreign aid donor wishes to increase conflict. Even if a recipient wishes to avoid conflict, accepting aid may work counter to its preferences, as the donor's rivals may view such aid as a potential attempt to alter regional power relationships in ways that damage the rival. By increasing conflict, the donor may be able to punish its rival without directly involving itself in military conflict. ${ }^{41}$

Increased foreign aid to the recipient may create a threat to the donor's rival that it finds untenable. With the potential of increasingly strengthened ties between donor and recipient, and the added possibility of the donor increasing its military capability over time as a direct result of the aid, the donor's rival may choose to strike militarily before the recipient becomes an even greater threat to its security. Such an act may decrease the relative military strength of the donor's rival and divert its attention away from the donor. In both cases, this may be of benefit to the recipient, which manages to counter its rival without directly placing itself at risk, or bearing the direct military costs of the conflict.

On the other hand, the aid recipient may find itself in a form of security dilemma, in which the actions it takes to gain security instead result in increased threats. In the context of aid, its desire to accept aid for peaceful purposes may not be perceived in the same way by the donor's rival, whose reactions may therefore result in the direct opposite of the recipient's intentions. If this contending theoretical argument is at work, we might expect increasing levels of aid to the recipient to provoke the donor's rival to attack the recipient. Thus:

H2a: Increased aid to neighbors/rivals in common increases the use of force against the recipient by the donor's rival.

${ }^{41}$ Rudloff et al., "Countering Adversaries." 
Alternatively, a foreign aid recipient may not possess peaceful intentions, and aid that it receives may be used to promote its desire to act aggressively against other states. Although we argue that the intention of the donor is important in explaining states' conflict behavior, particularly in determining whether the donor's rival or the foreign aid recipient is the initiator of conflict, the intent of the donor may simply be ignored by the foreign aid recipient. ${ }^{42}$ In these cases, a donor may hope to decrease conflict through foreign aid, only to find that an unintended consequence of the aid is to increase conflict.

Foreign aid may increase the confidence of the recipient that it will be able to prevail in a conflict against the donor's rival, thus increasing the likelihood that it will attack. Even if the foreign aid does not increase the likelihood that the recipient will prevail in a conflict, it does allow the donor to fund conflict, making conflict more attractive as a foreign policy choice. Consider cases where the recipients of foreign aid engaged in provocative acts against a donor's rival, even when there were significant military or diplomatic costs. Examples include Israel's decision in 1981 to attack Iran's nuclear facility at Osirak, or Georgia's confident defiance of Russia prior to the 2008 conflict between the two states. In such cases, recipients may increase conflict-oriented behavior against other states, either at the behest of the donor state, or on its own initiative. Thus, Argument Two also suggests:

\section{H2b: Increased aid to neighbors/rivals in common increases the use of force by the recipient against the donor's rival.}

The provision of aid motivated by these indirect rivalry factors produces many possible effects in terms of increased conflict behavior. The key to understanding these effects is to consider the underlying motivations of aid donors and recipients, and how aid can be used to further the goals of both states, or potentially (in troubling cases from the view of the donor) be used in ways that run counter to the goals of the donor. In the logic of Argument One, (Hypotheses 1a and 1b), foreign aid works to decrease conflict. Conversely, according to the logic of Argument Two (Hypotheses 2a and 2b), the aid recipient can either be the target or the perpetrator of the use of force. Whatever the intention of the donor, increased conflict can result from an increase in aid from the donor. These cases of mixed motivation are perhaps the more interesting cases, as a recipient looking to promote economic growth through aid may find that this aid induces other states to act aggressively toward it, while donors looking to promote deterrence may find that aid recipients have their own plans for using the aid.

Although aid may lead to many different effects, and individual cases of each of these four hypothesized relationships may exist, we seek to examine whether any one of these relationships is more important than the others. We ask: Which of these contending arguments does the evidence best support? What does this evidence tell us about the role of foreign aid in conflict? The following section outlines our strategy for answering these questions using data on rivalry, conflict, and foreign aid.

\section{Research Design}

The hypotheses in the previous section emphasize the effects of aid on a subset of states,

42 Charles W. Kegley Jr. and Steven W. Hook, “U.S. Foreign Aid and U.N. Voting: Did Reagan's Linkage Strategy Buy Deference or Defiance?," International Studies Quarterly 35 (1991): 295-312; Mott, United States Military Assistance; Sullivan et al., "U.S. Military Aid." 
rather than all states. Specifically, we focus on those states that share a rival with a potential donor, as well as states that are proximate to a donor's rival. These states may be more likely to receive foreign aid as a result of indirect rivalry effects, ${ }^{43}$ and are therefore the subject of our theoretical arguments. Due to the limited availability of reliable and complete aid data, in this test of our argument, we limit our analysis to cases in which the US is the potential donor. Our unit of analysis is the state-year, and the time period of our study is 1962 to 2000. These years include data from the Cold War and post-Cold War periods, increasing the generalizability of the results by including cases from different international contexts.

To determine shared rivalry, we use the Klein, Goertz, and Diehl data on rivalry, which indicates that the US was involved in a number of rivalries between 1962 and 2000 (see Table 1). ${ }^{44}$ We utilize this data set because our interest is in cases that are more likely to be prone to international conflict as a result of rivalry, and unlike alternative rivalry measures ${ }^{45} \mathrm{Klein}$, Goertz, and Diehl base their rivalry measure directly on states' conflict behavior. These rivals span a number of regions, and their interactions are not limited to before or after the end of the Cold War. After determining US rivals, we use the same rivalry data ${ }^{46}$ to find which states are in a rivalry with the US rivals, limiting their inclusion in the data set to years when each of these states is a rival of the US in a particular year.

Table 1- US Rivals $1962-2000$

\begin{tabular}{c|c}
\hline Rival & Years of Rivalry (1962 - 2000) \\
\hline Canada & $1974-1997$ \\
\hline Cuba & $1962-1996$ \\
\hline Nicaragua & $1982-1988$ \\
\hline Ecuador & $1962-1981$ \\
\hline Peru & $1962-1992$ \\
\hline Yugoslavia & $1992-2000$ \\
\hline Russia & $1962-2000$ \\
\hline Libya & $1973-1996$ \\
\hline Iran & $1979-1997$ \\
\hline Iraq & $1987-2000$ \\
\hline Egypt & $1962-1968$ \\
\hline Syria & $1970-1996$ \\
\hline Afghanistan & $1998-2000$ \\
\hline China & $1962-2000$ \\
\hline North Korea & $1962-2000$ \\
\hline Vietnam & $1962-1973$ \\
\hline
\end{tabular}

Source: Klein, Goertz, and Diehl, "The New Rivalry Dataset".

We use Gleditsch and Ward's data ${ }^{47}$ to determine whether a state is a neighbor of a US rival. Per their specification, we include states that are within 950 kilometers of each of the US rivals identified in Table 1. A state year is only included if the state is a neighbor of a US rival in the same year that it is both geographically near that state and the state is a US rival. Although we run subsequent analyses on the shared rivalry and the neighbors of rival

43 Rudloff et al., "Countering Adversaries."

44 James P. Klein, Gary Goertz and Paul F. Diehl, "The New Rivalry Dataset: Procedures and Patterns," Journal of Peace Research 43, no.3 (2006): 331-348.

45 E.g., William R. Thompson, "Identifying Rivals and Rivalries in World Politics," International Studies Quarterly 45 (2001): 557-586; Colaresi, Rasler and Thompson, Strategic Rivalries.

46 Klein, Gary Goertz and Paul F. Diehl, "The New Rivalry Dataset."

47 Kristian S. Gleditsch and Michael D. Ward, "Measuring Space: A Minimum Distance Database and Applications to International Studies," Journal of Peace Research 38, no.6 (2001): 739-758. 
data separately as a check against the application of our arguments across multiple contexts, it is important to note that there is overlap in these two sets of cases. There are a number of states that are located near US rivals that are also in a rivalry with the US rival. Therefore, the rivalry and neighbor data sets should not be treated as mutually exclusive.

Our dependent variable is conflict between states. To measure this concept, we utilize the Correlates of War Militarized Interstate Dispute Dataset. ${ }^{48}$ Using EUGene, we generate conflict data, and then use this data to collect four different variables to measure the conflict between potential foreign aid recipients and US rivals. ${ }^{49}$ Our hypotheses indicate that we must distinguish between whether a state is an initiator of a dispute or a target of a dispute, so we construct multiple dependent variables to be utilized in our analysis.

The first variable is a dichotomous variable indicating whether there was a militarized interstate dispute in a year where the aid recipient initiated a conflict with a rival of the US in the given year. ${ }^{50}$ The second variable is a dichotomous variable indicating whether there was a militarized interstate dispute where the aid recipient was a target of a militarized interstate dispute initiated by a US rival in the given year. ${ }^{51}$ Both variables include all types of conflicts in the data, which range from war between states to threats between states. ${ }^{52}$ We also code a variable that includes only military conflicts that led to a death, ${ }^{53}$ to account for the possibility that the severity of the conflict may partly determine the decision-making logic of the states involved. ${ }^{54}$ For each of these conflict variables, we construct a separate variable for each category of potential aid recipient: neighbors of US rivals, and rivals of US rivals.

The foreign aid data for our study is from Bueno de Mesquita and Smith's foreign aid data set, which itself is derived from the USAID's Greenbook..$^{55}$ Due to the availability of US foreign aid data, we focus on the US as the foreign aid donor in this study. Furthermore, although USAID differentiates between military and economic aid, for our purposes, we use total US aid to recipient states per year, because we do not make any theoretical arguments regarding the differences in aid type on conflict between states. Aid data is potentially problematic because a number of states receive no foreign aid in a given year. Moreover, the distribution of aid among recipients leads some to log aid variables in their analyses. ${ }^{56}$ Logging the aid variable, however, means that those states that do not receive aid will be dropped from the analysis, even though these states are an important segment of cases. We therefore present the analysis without logging the aid variable, but we note any differences that result from substituting the logged aid variable in the results section.

We include a series of control variables that might explain a state's conflict behavior. First, to control for the effect of regime type, we include a democracy variable from the Polity IV data set that varies between -10 and 10, with higher numbers representing greater levels of

48 Faten Ghosn and Glenn Palmer, "Codebook for the Militarized Interstate Dispute Data, Version 3.0," April 14, 2003, accessed October 18, 2011, www.correlatesofwar.org/COW2\%20Data/MIDs/MID_v3.0.codebook.pdf.

49 D. Scott Bennett and Allan C. Stam, "EUGene: A Conceptual Manual," International Interactions 26, no.2 (2000): 179-204.

50 For each of the four conflict variables, we utilize the default definition of "initiator" included in EUGene. See Bennett and Stam, "EUGene." See Ghosn and Palmer, "Militarized Interstate Dispute Data" for how the Correlates of War Project codes its conflict variables.

51 Faten Ghosn, Glenn Palmer, and Stuart Bremer, "The MID3 Data Set, 1993-2001: Procedures, Coding Rules, and Description," Conflict Management and Peace Science 21, no.2 (2004): 133-154

52 Ghosn and Palmer, "Militarized Interstate Dispute Data."

53 Ibid.

54 Although we do not include tables with results for these alternative conflict variables (in order to aid comprehension of the results), we do discuss the findings using these variables in the text.

55 Bruce Bueno de Mesquita and Alastair Smith, "Foreign Aid and Policy Concessions," Journal of Conflict Resolution 51, no.2 (2007): 251-284; “Greenbook," US Overseas Loans and Grants, USAID, February 18, 2011, http://www.usaid.gov/policy/ greenbook.html.

56 Mesquita and Smith, "Foreign Aid." 
democracy. ${ }^{57}$ Second, we include a dichotomous variable indicating whether a potential aid recipient is itself a rival of the US, which we derive from Klein, Goertz, and Diehl's rivalry data. ${ }^{58}$ This is necessary because a number of US rivals are geographically proximate to one another (see Table 1), and may themselves be rivals with one another. By indicating which potential recipients are also rivals of the US, we control for the possibility that these potential recipients are much less likely to receive aid, despite their shared rivalry or proximity to a US rival. ${ }^{59}$ Third, to gauge the effect of common political interests, we include Signorino and Ritter's "S-score" between each potential recipient and the US, ${ }^{60}$ which was drawn from EUGene. Fourth, we include a count variable of the number of US rivals the recipient state shares a rivalry with (in the shared-rivalry analysis) or is a neighbor to (in the neighbor-ofrival analysis) in a particular year. This inclusion helps control for the possibility that states associated (either through rivalry or proximity) with greater numbers of rivals may be more likely to engage in conflict with at least one of these rivals, and are also more likely to receive greater amounts of aid given their association with more US rivals. Finally, to control for the economic development of the potential recipient state, we include the gross domestic product (hereafter GDP) per capita variable from Bueno de Mesquita and Smith, which was originally drawn from World Bank economic data. ${ }^{61}$ The GDP per capita variable is adjusted for inflation, and is measured in constant US dollars. In the statistical analysis, the aid, GDP per capita, democracy, and S-score variables are lagged by one year.

Each of the four dependent variables in our analysis is dichotomous, therefore all subsequent analysis is conducted using logistic regression. A number of issues arise from our data, however, that must be accounted for to ensure the quality of the statistical results. First, the unit of analysis is state-year, and each state may be in the data set for a number of years. Given that a state's foreign policy behavior in consecutive years is related, we must control for the lack of independence between observations. ${ }^{62}$ To do this, we calculate a new variable representing the number of years since at least one conflict occurred involving the potential aid recipient. ${ }^{63}$ This variable, denoted as "Peace Years" in subsequent analyses, also helps control for the clustering of conflict across time, as there may be periods in a state's history when it is more likely to engage in conflict due to short-term disputes with other states. Using this variable as a baseline, we then include a squared and a cubed version of this variable, as suggested by Carter and Signorino. ${ }^{64}$ Finally, we include robust standard errors, clustered by state.

Subsequent analysis lends itself to isolating the expected relationship between foreign aid and the potential for conflict in these indirect rivalry situations. For example, a simple

57 Monty Marshall and Keith Jaggers, "Polity IV Project: Political Regime Characteristics and Transitions, 1800-2007," Center for Systemic Peace, http://www.systemicpeace.org/polity/polity4.htm.

58 Klein, Goertz, and Diehl, "The New Rivalry Dataset."

59 E.g. Rudloff et al., "Countering Adversaries."

${ }^{60}$ Curtis S. Signorino and Jeffrey M. Ritter, "Tau-b or Not Tau-b: Measuring the Similarity of Foreign Policy Positions," International Studies Quarterly 43, no.1 (1999).

${ }_{61}$ Mesquita and Smith, "Foreign Aid"; World Bank, 2011, http://data.worldbank.org.

62 Nathaniel Beck, Jonathan N. Katz, and Richard Tucker, "Taking Time Seriously: Time-Series-Cross-Section Analysis with a Binary Dependent Variable," American Journal of Political Science 42, no.4 (1998): 1260-1288.

${ }_{63}$ We utilized the BTSCS Stata package to create this variable (Beck, Katz, and Tucke, "Taking Time Seriously"; Richard Tucker, BTSCS: A Binary Time-Series-Cross-Section Data Analysis Utility. Version 4.0.4. (Cambridge, MA: Harvard University, 1999)), which is available at http://www.prio.no/CSCW/Datasets/Stata-Tools/.

${ }_{64}$ David B. Carter and Curtis S. Signorino, "Back to the Future: Modeling Time Dependence in Binary Data," Political Analysis 18, no.3 (2010): 271-292. 
correlation between aid and conflict may indicate evidence for our earlier arguments (that aid either increases or decreases the likelihood of a state engaging in conflict). However, it may also indicate something about US decision making in regard to aid. A positive correlation between aid and conflict may indicate that the US is more likely to give aid proactively to those states that are willing to engage in conflict with its rival(s), and this possibility is largely indistinguishable from the alternative that we are interested in - that recipient states use the benefits of this aid to engage in conflict with their rivals.

Although this possibility is problematic, our analysis mitigates it in a number of ways. First, we distinguish between those states that are rivals of US rivals, and those that are simply neighbors of US rivals. If the US anticipates conflict, we are likely to see a statistically significant effect in the former case, but not the latter. If the recipient state is engaged in a rivalry with the US rival, it has already demonstrated a history of conflict with the US rival. These rivals are much more likely to engage in conflict than neighbors. In addition, the Peace Years variable used to account for temporal dependence has the beneficial side effect of controlling for recent conflict history, as potential aid recipients that have recently engaged in conflict may be more likely to engage in conflict in the near future (regardless of whether or not they receive aid from the US). If this is the case, we expect the Peace Years variable to be negatively associated with conflict in a given year, as longer periods of peace will make a new conflict less likely.

\section{Analysis}

Our analysis focuses on two types of potential recipients: rivals of US rivals, and neighbors of US rivals. Our hypotheses suggest that there may also be differences between the conflict behavior of aid recipients and US rivals, so for each of the analyses, we present a separate analysis for cases when the aid recipient initiated conflict, and cases where the aid recipient was targeted by a US rival.

\begin{tabular}{c|c|c}
\hline Table 2- Neighbors of Rivals (Conflict Initiation versus Targeting) \\
\hline \multirow{2}{*}{ Total Aid } & Recipient Initiates & Recipient Targeted \\
& $0.0003^{* * *}$ & 0.00009 \\
$(0.00007)$ & $0.00008)$ \\
\hline Log of GDP & -0.038 & $0.445^{* *}$ \\
per capita & $(0.229)$ & $(0.148)$ \\
\hline \multirow{2}{*}{ Democracy } & 0.029 & 0.031 \\
& $(0.023)$ & $(0.018)$ \\
\hline \multirow{2}{*}{ S-score } & 0.170 & $-1.514^{*}$ \\
& $(0.868)$ & $(0.755)$ \\
\hline \multirow{2}{*}{ US Rival } & $1.280^{* * *}$ & $0.766^{*}$ \\
& $(0.362)$ & $(0.330)$ \\
\hline \multirow{2}{*}{ Number Rival Neighbors } & $0.427^{* *}$ & $0.371^{* * *}$ \\
& $(0.145)$ & $(0.098)$ \\
\hline \multirow{2}{*}{ Peace Years } & $-0.195^{*}$ & $-0.218^{* *}$ \\
& $(0.095)$ & $(0.064)$ \\
\hline \multirow{2}{*}{ Peace Years } & 0.006 & 0.004 \\
& $(0.007)$ & $(0.005)$ \\
\hline \multirow{2}{*}{ Peace Years } & -0.0006 & 0.00005 \\
& $(0.0001)$ & $(0.0001)$ \\
\hline \multirow{2}{*}{ Constant } & $-3.148^{* *}$ & $-3.118^{* * *}$ \\
& $(1.097)$ & $(0.710)$ \\
\hline & $\mathrm{n}=1915$ & $\mathrm{n}=1915$ \\
\hline \multirow{2}{*}{} & $($ Numbers in parentheses are robust standard errors.) \\
\hline
\end{tabular}


Table 2 summarizes the results for potential recipients that are neighbors of US rivals. The preliminary results indicate that foreign aid to neighbors of rivals increases the likelihood that these recipients will initiate conflict with US rivals, but there is little evidence to suggest that aid increases the likelihood that these states will be targeted by US rivals. The aid variable in the first model, which measures aid recipient initiations against US rivals, is positive and statistically significant, but the aid variable measuring rival conflict initiations against the aid recipient is not statistically significant. This is consistent with the expectations in Hypothesis 2b.

For example, Albania was a neighbor of a US rival (i.e., Serbia) from 1992 to $2000 .{ }^{65}$ Aid from the US decreased from 1992 to 1995 (after the end of the Cold War), but began to increase sharply again in 1996, and continued to increase until $2000{ }^{66}$ It is during this period of increase that Albania was more likely to initiate conflict with Serbia: once in 1998 and again in $2000{ }^{67}$ This case may illustrate Albania's willingness to increase its aggressiveness towards US rivals when it receives more aid from the US.

Furthermore, foreign aid seems to be associated with a significant increase in conflict between recipients and US rivals (See Table 3 for a summary of the predicted probabilities). For all of the predicted probability analyses, all variables other than foreign aid are set either at their mean or median, except for US rivals, which is set at $0 .{ }^{68}$ Given these values, when a neighbor of a US rival receives no aid from the US, the predicted probability that it initiates a conflict in a given year is only $1.5 \%$. However, when foreign aid is increased to the aid variable's mean plus two standard deviations, this probability increases to $2.2 \%$, an increase of over $45 \% .{ }^{69}$ There are two notes of caution about these predicted probabilities, however. First, the $95 \%$ confidence intervals around the predicted probability of conflict at this minimum and maximum overlap. Second, there is great deal of skew in the total aid variable, as there are clear outliers in terms of states that receive a great deal of aid from the US compared to other states. ${ }^{70}$

\begin{tabular}{l|l|l|l|l}
\hline Table 3- Predicted Probabilities of Conflict* \\
\hline & $\begin{array}{l}\text { Total Aid } \\
\text { (minimum) }\end{array}$ & $\begin{array}{l}\text { Total Aid } \\
\text { (mean + 2 s.d.) }\end{array}$ & $\begin{array}{l}\text { Total Aid } \\
\text { (maximum) }\end{array}$ & $\begin{array}{l}\text { Change in Prob. } \\
\text { (min to max) }\end{array}$ \\
\hline Neighbor of Rival Initiates & $1.5 \%$ & $2.2 \%$ & $15.5 \%$ & $\begin{array}{l}933 \% \\
\text { increase }\end{array}$ \\
\hline Rival of Rival Initiates & $6.6 \%$ & $10.2 \%$ & $29.1 \%$ & $\begin{array}{l}341 \% \\
\text { increase }\end{array}$ \\
\hline
\end{tabular}

* Variables "Rival of Rival Targeted" and "Neighbor of Rival Targeted" are statistically insignificant and thus not included. Note: Confidence intervals for predicted probabilities of conflict for minimum and maximum levels of total aid overlap.

65 Klein, Goertz, and Diehl, "The New Rivalry Dataset."

66 Mesquita and Smith, "Foreign Aid."

67 Ghosn, Palmer, and Stuart Bremer, "The MID3 Data Set."

68 To calculate the predicted probabilities throughout this paper, we utilized the SPOST package (Long, J. Scott and Jeremy Freese, Regression Models for Categorical Dependent Variables Using Stata. Second edition (College Station, TX: Stata Press, 2006), http://www.indiana.edu/ jslsoc/spost.html).

69 Table 3 also reports the predicted probability of conflict when the aid variable is set at its maximum. Although this change significantly increases the apparent impact of the aid variable, it is not necessarily an appropriate comparison, given that there are significant positive outliers in terms of the amount of foreign aid received by the US. We therefore present the comparison between the minimum and the mean plus two standard deviations throughout the text, because this encapsulates a much more appropriate range of the aid variable.

70 We run additional models replacing the total aid with the log of total aid. These models are problematic due to the number of states that did not receive any aid from the US during the time period of our analysis. When taking the log, these states drop from the analysis. In the case of the models in Table 2, over 500 observations drop from the analysis. Despite this drop, the logged aid variable is significant with a $p$-value of 0.059 , which is remarkable given that almost a third of the cases drop from the analysis. We argue that the total aid variable is more appropriate, because it allows us to measure the full range of US aid observed, and it allows for easier interpretation of the variable. Although they are outliers, cases where the US presented states with a disproportionately large amount of aid should be considered along with the much larger number of cases where the US chose not to give any aid. 
Returning to Table 2, there are relatively few control variables that are statistically significant. For example, the variable indicating whether a potential recipient is itself a US rival is positive and statistically significant in the model that measures recipient conflict initiation, indicating that these states are much more likely to initiate conflict. Furthermore, the variable indicating the number of US rivals with whom a potential recipient shares rivalries is also significant, which is unsurprising given that states with a greater number of shared rivals have a greater likelihood of initiating conflict with at least one of these rivals. Although the control variables are not statistically significant, this result may be due to the relatively small sample size of $(n<2000)$. This small size, however, makes the significance of the total aid variable even more striking.

In general, there is no evidence in this analysis that suggests that foreign aid leads to less conflict, as the first contending argument (Hypotheses 1a and 1b) suggests. It would seem that foreign aid has a significant inflammatory effect in these situations. Furthermore, if we only include conflicts that led to at least one death in the dependent variable, both of the total aid variables in these models remain statistically significant and positive. Given the evidence, it would seem that while US rivals are no more likely to initiate conflicts in general with neighbors that receive aid from the US, those rivals are more likely to initiate conflicts against the aid recipient when we consider only the most severe cases (Hypothesis 2a). Again, the weight of evidence suggests that aid to states in indirect rivalry conditions increases the likelihood that these states will attack US rivals. There is also evidence that US rivals are likely to initiate conflicts against aid recipients when we isolate the most severe cases of conflict.

Table 4 illustrates the results for potential recipients that are the rivals of US rivals. In this case, the number of observations is much smaller (660 observations, instead of 1915 when one includes neighbors of US rivals), as states are much more likely to be near a rival than to be in a rivalry with a US rival. In this case only one of the aid variables - for the recipient initiation model - is both positive and statistically significant, at the 0.05 level. Once again, there is some evidence that recipients of US aid are more likely to initiate conflict with US rivals as the amount of aid increases, and is further support for Hypothesis $2 \mathrm{~b}$. The statistical significance of the aid variables disappears in the case of recipient initiation with the substitution of logged foreign aid for total foreign aid. However, the sample size in the case of logged aid is only 375 compared to 660 due to dropped cases. On the other hand, if one excludes conflicts that did not lead to at least one death, both of the total aid variables summarized in Table 4 are statistically significant and positive, which indicates that total aid is associated positively with the most-violent conflict initiations. Again, the weight of evidence supports Hypothesis $2 b$, both for all conflicts and for the more severe conflicts. Hypothesis 2 a receives only some support, and this is limited to the more-severe cases, where at least one death was recorded in the conflict. Hence, the second contending argument is better supported by the empirical evidence of our test. 


\begin{tabular}{c|c|c}
\hline Table 4- Rivals of Rivals (Conflict Initiation versus Targeting) \\
\hline & Recipient Initiates & Recipient Targeted \\
\hline \multirow{2}{*}{ Total Aid } & $0.0002^{*}$ & -0.00001 \\
& $(0.00009)$ & $(0.00006)$ \\
\hline Log of GDP & -0.322 & 0.042 \\
per capita & $(0.280)$ & $(0.186)$ \\
\hline \multirow{2}{*}{ Democracy } & -0.010 & 0.030 \\
& $(0.032)$ & $(0.023)$ \\
\hline \multirow{2}{*}{ S-score } & 0.607 & -1.463 \\
& $(1.291)$ & $(1.014)$ \\
\hline \multirow{2}{*}{ US Rival } & $1.270^{* * *}$ & $0.662^{*}$ \\
& $(0.348)$ & $(0.306)$ \\
\hline \multirow{2}{*}{ Number of Shared Rivals } & $0.747^{* * *}$ & $0.629^{* * *}$ \\
Peace Years & $(0.170)$ & $-0.142)$ \\
\hline \multirow{2}{*}{ Peace Years ${ }^{2}$} & -0.049 & $(0.112)$ \\
\hline \multirow{2}{*}{ Peace Years } & $(0.100)$ & 0.022 \\
& -0.00007 & $(0.015)$ \\
\hline \multirow{2}{*}{ Constant } & $(0.010)$ & -0.0004 \\
& 0.00003 & $(0.0004)$ \\
\hline & $(0.0002)$ & -1.321 \\
& -2.259 & $(0.756)$ \\
\hline & $(1.156)$ & $\mathrm{n}=660$ \\
\hline & $n=660$ & $($ Numbers in parentheses are robust standard errors.) \\
\hline & $*=p<0.05, * *=p<0.01, * * *=p<0.001$ \\
\hline
\end{tabular}

Given these results, is it possible that it is not the aid that is causing greater levels of conflict, but the fact that the US directs more aid to states that are most likely to be involved in conflict in the future? That is, it is not US aid that is causing conflict, but some other factors that are also causing the US to give aid to these states. To mitigate this possibility, we have taken several steps. First, we control for a number of economic and political factors that may also be associated with conflict, which would help isolate the effects of aid on conflict. Second, we believe that one of the best predictors of future conflict in these cases is past conflict, which is inherent in the rivalry data that we are using. ${ }^{71}$ If this is the case, then we are also likely to control for the possibility of future conflict through the variable measuring the number of peace years since the previous conflict. Note that in each of the models presented, the Peace Years variable is negative (although not always statistically significant), indicating that as the number of years since the previous conflict increases, the likelihood of conflict occurring in a given year decreases. Finally, the main finding in support of the first contending argument - that increased levels of aid lead to greater levels of recipient conflict initiation - is robust, regardless of whether one considers only rivals (Table 4), or adds the neighbors of the recipient state to the sample (Table 2). Ultimately, by considering two different samples, and controlling for factors that may also predict the level of conflict between the relevant pairs of states (based on both rivalry and proximity), we better isolate the influence of aid on conflict involvement in recipient states.

Returning to Table 3, which contains the predicted probabilities for all the models, there is a significant increase in the predicted probability of conflict when one increases total aid from its minimum to the variable's mean plus two standard deviations. In the case of aid

\footnotetext{
71 Klein, Goertz, and Diehl, "The New Rivalry Dataset."
} 
to states that share a rival with the US, the predicted probability of a recipient initiating conflict against a US rival increases from $6.6 \%$ to $10.2 \%$, for a $55 \%$ increase in the predicted probability of an aid recipient initiating conflict with a US rival.

An example of a state that is more likely to initiate conflict against a US rival when receiving more US aid is Saudi Arabia, which was involved in two distinct periods of rivalry with US rivals during our period of study: from 1962 to 1967 and then from 1984 until $2000 .{ }^{72}$ Saudi Arabia received virtually no aid from the US in the latter period, ${ }^{73}$ nor did it initiate a conflict with a US rival from the mid-1980s onward. ${ }^{74}$ On the other hand, Saudi Arabia did receive aid from the US between 1962 and $1967,{ }^{75}$ and in this short period of time it initiated two conflicts with Egypt, a US rival. ${ }^{76}$ In 1962 Saudi Arabia initiated a conflict against Egypt and the Yemen Arab Republic, and in 1964 initiated a conflict against Egypt alone..$^{77}$ Although the motivations of Saudi Arabia and the US may be different in the region, it is important to note that the US still receives the benefit of another state targeting its rival with conflict.

Given that there is a statistically significant relationship between aid and conflict in Table 2 and in Table 4, we have less reason to be concerned that this is an artifact of US aid decision making. If the US were simply giving more aid to states that were predisposed to fight its rivals, we would expect there to be a positive and statistically significant relationship in Table 4, but not necessarily in Table 2. Instead, we find that this positive relationship exists in both sets of data. Although it is impossible to completely eliminate the possibility that we are misinterpreting the direction of causality, current evidence suggests this is not the case.

\section{Discussion and Conclusion}

In general, our statistical results demonstrate that there is little evidence that aid to neighbors of US rivals or to rivals of US rivals decreases the likelihood of conflict between these recipients and the US rivals. To the contrary, the evidence robustly indicates that aid in indirect rivalry situations greatly exacerbates conflict within these contexts. We find little evidence that aid leads to "extended deterrence." of a recipient initiating conflict against a rival, and to a lesser degree appears to increase the chances of the recipient being targeted by a US rival. Furthermore, the significance of the aid variable is most consistent across models when we consider only conflicts that lead to at least one death. This indicates that not only does foreign aid lead to more conflict in these cases, but it leads to more-violent conflict as well.

Interestingly, the results are a bit more consistent in the sample of neighbors of US rivals, rather than rivals of US rivals (due to the fact that the logged aid variable at least approaches statistical significance at the 0.05 level, despite the large number of dropped cases). On the one hand, this result is surprising, given that one might expect that conflict is more likely to be prompted in cases where foreign aid recipients already have a ready enemy. However, rivalry also means that conflict is already occurring between states, so it may be the case that while foreign aid may spark conflict between states, it is less likely to escalate conflict

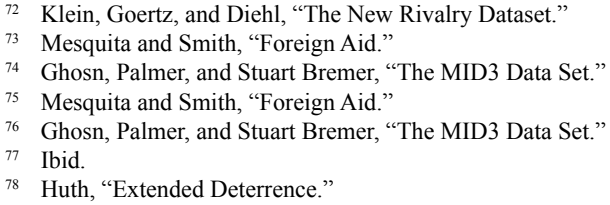


between states already engaged in persistent conflict with one another. It is possible that foreign aid may help lead to the creation of rivalries among neighbors, but this is an empirical question that would need to be addressed in a subsequent analysis.

As we stated at the outset, foreign aid is an important foreign policy tool for major powers, and existing research demonstrates the diversity of goals that can be achieved through the use of aid..$^{79}$ However, the arguments and evidence in this paper demonstrate the need for caution in the provision of foreign aid. Donors appear to respond to indirect rivalry situations by providing greater amounts of assistance in many cases.$^{80}$ In these situations, states may wish only to support states against rivals in a manner than makes conflict less likely. Nevertheless, our statistical analysis demonstrates that aid does not appear to decrease conflict between states. To the contrary, aid appears, at least in some cases, to increase the probability of conflict between recipients and the rivals of donors. This is yet another potential "unintended consequence" of aid. ${ }^{81}$ Foreign aid meant to support the security of states may ultimately undermine that security, either by prompting the state to engage in conflict, or by inviting attack from US rivals.

Although this analysis provides an initial examination of the potential conflict-increasing effects of aid, much more work is needed to determine whether there is consistent evidence that aid increases conflict in these indirect rivalry situations. For example, we examine only a single donor, the US, and, although that country is an important foreign aid donor, this limits the generalizability of the results. By extending the number of potential donors considered, the results will not only become more generalizable, but more consistent with larger sample sizes. Furthermore, future analyses should disaggregate foreign aid into economic and military components to evaluate whether different forms of assistance are associated with different consequences for conflict. Although the argument presented in this paper does not theoretically distinguish between types of aid, such a distinction may help identify more specific contingencies in which aid is more likely to lead to conflict or peace. Despite the findings of this study suggesting that aid to states that share a rival will be associated with conflict initiation against the rival from the aid recipient, it is possible that there are specific conditions under which aid may be bring less conflict. Finally, a future study can also make a substantive contribution by examining conflict behaviors other than initiation. For example, states may be more likely to escalate to higher levels of conflict when given aid, or may be more likely to engage in conflict with a larger number of states. Nevertheless, our analysis suggests that, while donors may provide aid in the context of rivalry situations for a variety of strategic purposes, they may in fact be 'buying trouble' when they do so.

79 E.g., McKinlay and Little, "A foreign policy model”; Lebovic, "National Interests and US Foreign Aid"; Hook, Foreign Aid; Meernik, Krueger and Poe, "Testing models of U.S. foreign policy”; Schraeder et al.,"Clarifying the Foreign Aid Puzzle."

${ }^{80}$ Rudloff et al., "Countering Adversaries."

81 Mott, United States Military Assistance; Collier and Hoeffler, "Unintended Consequences”; Sullivan et al., "US Military Aid." 


\section{Bibliography}

Alesina, A. and Dollar, D. "Who gives foreign aid to whom and why?" Journal of Economic Growth 5 (2000): 33-63.

Barnett Michael and Martha Finnemore. Rules for the World: International Organizations in Global Politics. Ithaca: Cornell University Press, 2004.

Beck, Nathaniel, Jonathan N. Katz, and Richard Tucker. "Taking Time Seriously: Time-Series-Cross-Section Analysis with a Binary Dependent Variable.” American Journal of Political Science 42, no.4 (1998): 12601288.

Bendor, Jonathan, A. Glazer, and Thomas Hammond. "Theories of Delegation.” Annual Review of Political Science 4 (2001): 235-69.

Bennett, D. Scott and Allan C. Stam. "EUGene: A Conceptual Manual.” International Interactions 26, no.2 (2000): 179-204.

Blouin, Max and Stéphane Pallage. "Humanitarian Relief and Civil Conflict." Journal of Conflict Resolution 52, no.4 (2008): 548-565.

Bobrow, Davis B., P. Terrence Hopmann, Roger W. Benjamin, and D. A. Sylvan. "The Impact of Foreign Assistance on National Development and International Conflict.” Journal of Peace Science 1, no.1 (1973): 39-60.

Boschini, Anne and Anders Olofsgard. "Foreign Aid: An Instrument for Fighting Communism." Journal of Development Studies 43 (2007): 622-648.

Bueno de Mesquita, Bruce and Alastair Smith. "Foreign Aid and Policy Concessions." Journal of Conflict Resolution 51, no.2 (2007): 251-284.

Burnside, C. and D. Dollar. “Aid, Policies and Growth.” American Economic Review 90 (2000): 847- 868.

Carter, David B. and Curtis S. Signorino. "Back to the Future: Modeling Time Dependence in Binary Data." Political Analysis 18, no.3 (2010): 271-292.

Cassen, R. Does Aid Work? 2d Ed. Oxford. Clarendon Press, 1994.

Center for the Study of Civil War. Accessed November 4, 2011. http://www.prio.no/CSCW/Datasets/Stata-Tools/.

Colaresi, Michael P., Karen A. Rasler, and William R. Thompson. Strategic Rivalries in World Politics: Position, Space, and Conflict Escalation. Cambridge: Cambridge University Press, 2007.

Collier, P. and D. Dollar. Development Effectiveness: What Have We Learned? Washington, DC: World Bank, 2001. Collier, Paul. Wars, Guns and Votes: Democracy in Dangerous Places. New York: Harper, 2009.

Collier, Paul and Anke Hoeffler. "Aid, Policy, and Peace: Reducing the Risks of Civil Conflict." Defence and Peace Economics 13, no.6 (2002): 435- 450.

Collier, Paul and Anke Hoeffler. "Unintended Consequences: Does Aid Promote Arms Races?" Oxford Bulletin of Economics and Statistics 69, no.1 (2007): 1-27.

Cox, Eric W. Why Enduring Rivalries Do -or Don't - End. Boulder, CO: Lynne Rienner, 2010.

Crawford, G. "Foreign Aid and Political Conditionality: Issues of Effectiveness and Consistency." Democratization 4 (1997): 69-108.

de Ree, Joppe and Eleonora Nillesen. "Aiding Violence or Peace? The Impact of Foreign Aid on the Risk of Civil Conflict in Sub-Saharan Africa.” Journal of Development Economics 88, no.2 (2009): 301-313.

Derouen, Karl, and Uk Heo. "Reward, Punishment or Inducement? US Economic and Military Aid, 1946-1996." Defence \& Peace Economics 15, no.5 (2004): 453-470.

Diehl, Paul F. and Gary Goertz. War and Peace in International Rivalry. Ann Arbor, MI: University of Michigan Press, 2000.

Easterly, William. “Can Foreign Aid Buy Growth?” Journal of Economic Perspectives 17, no.3 (2003): 23-48.

Easterly, W. The White Man's Burden: Why the West's Efforts to Aid the Rest Have Done So Much Ill and So Little Good. New York: Penguin, 2006.

Epstein David and Sharyn O'Halloran. Delegating Powers: A Transaction Cost Politics Approach to Policy Making Under Separate Power. Cambridge: Cambridge University Press, 1999. 
Fariss, Christopher. "The Strategic Substitution of United States Foreign Aid.” Foreign Policy Analysis 6 (2010): 107-131.

Feyzioglu, Tarhan, Vinaya Swaroop \& Min Zhu. "A Panel Data Analysis of the Fungibility of Foreign Aid." The World Bank Economic Review 12, no.1 (1998): 29-58.

Findley, Michael G. and Tze Kwang Teo. "Rethinking Third-Party Interventions into Civil Wars: An Actor-Centric Approach.” Journal of Politics 68 (2006): 828-837.

Fleck, Robert K. and Christopher Kilby. "Changing aid regimes? US foreign aid from the Cold War to the War on Terror.” Journal of Development Economics 91 (2010): 185-197.

Ghosn, Faten and Glenn Palmer. "Codebook for the Militarized Interstate Dispute Data, Version 3.0." April 14, 2003. Accessed October 18, 2011, www.correlatesofwar.org/COW2\%20Data/MIDs/MID_v3.0.codebook.pdf.

Ghosn, Faten, Glenn Palmer, and Stuart Bremer. “The MID3 Data Set, 1993-2001: Procedures, Coding Rules, and Description.” Conflict Management and Peace Science 21, no.2 (2004): 133-154.

Gleditsch, Kristian S. and Michael D. Ward. "Measuring Space: A Minimum Distance Database and Applications to International Studies." Journal of Peace Research 38, no.6 (2001): 739-758.

Goertz, Gary and Paul F. Diehl. "Taking "Enduring” Out of Enduring Rivalry: The Rivalry Approach to War and Peace.” International Interactions 21, no.3 (1995): 291-308.

Hassler, Bjorn. "Foreign Assistance as a Policy Instrument: Swedish Environmental Support to the Baltic States, 1991-96." Cooperation and Conflict 37 (2002): 25-45.

Hawkins, Darren, David Lake, Daniel Nielsen and Michael Tierney, eds. Delegation and Agency in International Organizations. New York: Cambridge University Press, 2006.

Hook, Steven. Foreign Aid in the National Interest. Boulder, CO: Lynne Rienner Press, 1995.

Huth, Paul K. "Extended Deterrence and the Outbreak of War." American Political Science Review 82, no.2 (1988): 423-443.

Jones, Daniel M., Stuart A. Bremer, J. David Singer. “Militarized Interstate Disputes, 1816-1992: Rationale, Coding Rules, and Empirical Patterns." Conflict Management and Peace Science 15, no.2 (1996): 163-212.

Kegley, Charles W., Jr and Steven W. Hook. "U.S. Foreign Aid and U.N. Voting: Did Reagan's Linkage Strategy Buy Deference or Defiance?” International Studies Quarterly 35 (1991): 295-312.

Kiewiet Roderick and Mathew McCubbins. The Logic of Delegation. Chicago: University of Chicago Press, 1991.

Klein, James P., Gary Goertz and Paul F. Diehl. "The New Rivalry Dataset: Procedures and Patterns.” Journal of Peace Research 43, no.3 (2006): 331-348.

Knack, S. Does Foreign Aid Promote Democracy? International Studies Quarterly 48 (2004): 251-266.

Lai, Brian. "Examining the Goals of US Foreign Assistance in the Post-Cold War Period, 1991-96." Journal of Peace Research 40 (2003): 103-128.

Lai, Brian, and Daniel S. Morey. "Impact of Regime Type on the Influence of U.S. Foreign Aid." Foreign Policy Analysis 2, no.4 (2006): 385-404.

Lancaster, Carol. Foreign Aid: Diplomacy, Development and Domestic Politics. Chicago: University of Chicago Press, 2007.

Lebovic, James H. "National Interests and US Foreign Aid: The Carter and Reagan Years." Journal of Peace Research 25 (1988): 115-135.

Long, J. Scott and Jeremy Freese. Regression Models for Categorical Dependent Variables Using Stata. Second edition. College Station, TX: Stata Press, 2006.

Lyne, Mona, Daniel Nielsen and Michael J. Tierney. "Getting the Model Right: Single, Multiple and Collective Principals in Development Aid.” In Delegation and Agency in International Organizations, edited by Hawkins et al. New York: Cambridge University Press, 2006.

Marshall, Monty and Keith Jaggers. Polity IV Project: Political Regime Characteristics and Transitions, 1800-2007. Center for Systemic Peace. http://www.systemicpeace.org/polity/polity4.htm.

McKinlay, R.D. and Little, R. “A foreign policy model of US bilateral aid allocation.” World Politics 30 (1977): 58-86. 
Meernik, James, Eric L. Krueger and Steven C. Poe. "Testing models of U.S. foreign policy: foreign aid during and after the Cold War." Journal of Politics 60 (1998): 63-85.

Mitchell, Sara McLaughlin and Brandon C. Prins. "Rivalry and Diversionary Uses of Force." Journal of Conflict Resolution 48, no.6 (2004): 937-961.

Moon, Bruce E. “The Foreign Policy of the Dependent State.” International Studies Quarterly 27 (1983): 315-340.

Mott, William H. United States Military Assistance: An Empirical Perspective. Westport: Greenwood Press, 2002.

Morey, Daniel S. "Conflict and the Duration of Peace in Enduring Rivalries." Conflict Management and Peace Science 26, no.4 (2009): 331-345.

Nielsen, Daniel and Michael Tierney. "Delegation to International Organizations: Agency Theory and World Bank Environmental Reform.” International Organization 57 (2003): 241-76.

Nielsen, Richard A., Michael G. Findley, Zachary S. Davis, Tara Candland, Daniel L. Nielson. "Foreign Aid Shocks as a Cause of Violent Armed Conflict." American Journal of Political Science 55, no.2 (2011): 219-232.

Noel, Alain, and Jean-Philippe Therien. "Political Parties and Foreign Aid." The American Political Science Review 94 (2000): 151-162.

Palmer, Glenn, Scott B. Wohlander and T. Clifton Morgan. "Give or Take: Foreign Aid and Foreign Policy Substitutability." Journal of Peace Research 39 (2002): 5-26.

R Core Team. R: A Language and Environment for Statistical Computing. 2012. http://www.r-project.org/.

Rasler, Karen A. and William R. Thompson. "Contested Territory, Strategic Rivalry, and Conflict Escalation." International Studies Quarterly 50, no.1 (2006): 145-168.

Regan, P.M. "U.S. Economic Aid and Political Repression: An Empirical Evaluation of U.S. Foreign Policy." Political Research Quarterly 48 (1995): 613-628.

Richardson, Neil R. and Charles W. Kegley. "Trade Dependence and Foreign Policy Compliance: A Longitudinal Analysis.” International Studies Quarterly 24 (1980): 191-222.

Ruttan, Vernon W. United States Development Assistance Policy: The Domestic Politics of Foreign Aid. Baltimore: Johns Hopkins University Press, 1996.

Rudloff, Peter, James M. Scott, and Tyra Blew. "Countering Adversaries and Cultivating Friends: Indirect Rivalry Factors and Foreign Aid Allocation.” Cooperation and Conflict 48 (2013): 401-423.

Schraeder, Peter J., Steven W. Hook, and Bruce Taylor. "Clarifying the Foreign Aid Puzzle: A Comparison of American, Japanese, French, and Swedish Aid Flows.” World Politics 50 (1998): 294-323.

Scott, James M. Deciding to Intervene: The Reagan Doctrine and American Foreign Policy. Durham: Duke University Press, 1996.

Signorino, Curtis S. and Jeffrey M. Ritter. "Tau-b or Not Tau-b: Measuring the Similarity of Foreign Policy Positions.” International Studies Quarterly 43, no.1 (1999): 115-144.

Sullivan, Patricia L. Brock C. Tessman and Xiaojun Li. "US Military Aid and Recipient State Cooperation.” Foreign Policy Analysis. 7 (2011): 275-294.

Suzuki, Akisato and Neophytos Loizides. "Escalation of Interstate Crises of Conflictual Dyads: Greece-Turkey and India-Pakistan." Cooperation and Conflict 46 (2011): 21-39.

Tendler, Judith. Inside Foreign Aid. Baltimore: Johns Hopkins University Press, 1975.

Thompson, William R. Identifying Rivals and Rivalries in World Politics. International Studies Quarterly 45 (2001): 557-586.

Tucker, Richard. BTSCS: A Binary Time-Series-Cross-Section Data Analysis Utility. Version 4.0.4. Cambridge, MA: Harvard University, 1999.

USAID. US Overseas Loans and Grants. “Greenbook”. February 18, 2011. http://www.usaid.gov/policy/greenbook. html.

World Bank. 2011. http://data.worldbank.org.

Yoon, Mi Yung. "Explaining U.S. Intervention in Third World Internal Wars, 1945-1989." Journal of Conflict Resolution 41 (1997): 580- 602. 